\title{
Environmental and Cost Assessment of a Polypropylene Nanocomposite
}

\author{
A. L. Roes · E. Marsili $\cdot$ E. Nieuwlaar · \\ M. K. Patel
}

Published online: 19 August 2007

(C) Springer Science+Business Media, LLC 2007

\begin{abstract}
This paper describes a study on the use of a polypropylene (PP)/layered silicate nanocomposite as packaging film, agricultural film, and automotive panels. The study's main question was “Are the environmental impacts and costs throughout the life cycle of nanocomposite products lower than those of products manufactured from conventional materials?" The conventional (benchmark) materials studied were pure polypropylene as packaging film, pure polyethylene as agricultural film, and glass fiber-reinforced polypropylene as automotive panels. In all three cases, the use of the PP nanocomposite resulted in a reduction of the amount of material used, while ensuring the same functionality. Material reduction was estimated using Ashby's material indices and amounted to $-9 \%$ for packaging film, $-36.5 \%$ for agricultural film, and $-1.25 \%$ for automotive panels. It goes without saying that a product's impact on the environment will decrease when less material is used. The production and incorporation of nanoparticles, however, may have additional impacts. We found clear environmental benefits throughout the entire life cycle when the PP nanocomposite is used in the manufacture of agricultural film. We noted some cost benefits when the nanocomposite is used in the production of agricultural film and automotive panels. If the price of nanoclay is at most $€ 5,000$ tonne then the cost of nanocomposite packaging film is also lower than that of the conventionally produced product.
\end{abstract}

Keywords Life cycle assessment - Life cycle costing . Nanotechnology $\cdot$ Polypropylene nanocomposite

A. L. Roes $(\bowtie) \cdot$ E. Marsili · E. Nieuwlaar · M. K. Patel Department of Science, Technology and Society (STS), Utrecht University, Heidelberglaan 2, 3584 CS Utrecht, The Netherlands e-mail: a.1.roes@uu.nl

\section{Introduction}

Nanotechnology is a very promising field for industrial applications. In fact, several products are already on the market for certain niche sectors with high added value, e.g., biomedical materials and analytic devices. The real revolution in nanomaterial applications, however, is expected to involve widely used bulk products. Polymers like polyolefins and polyvinylchloride (PVC), for example, are good candidates in this respect because of their large-scale use and versatility. Indeed, one of the first applications of nanotechnology was the production of nanofillers for the improvement of the mechanical properties of polymers [13]. Polypropylene (PP) is particularly interesting because of its low cost and good mechanical properties. This polymer has been used in conventional composites for a long time and, in combination with nanofillers, shows better mechanical properties with even low amounts of filler. The main nanofillers used today are nanoclay (natural product) and carbon nanotubes (synthetic). Synthetic carbon nanotubes are very expensive. Nanoclays (layered silicates), in contrast, are especially interesting for bulk applications because they are relatively inexpensive and they cause an improvement in the mechanical properties of polymers. Commonly used nanoclays include montmorillonite, hectorite, and saponite, all of which belong to the same general family of 2:1 layered or phyllosilicates [4].

The addition of nanoclay increases not only the elasticity and strength of PP, but also its barrier and fire-retardant properties. In applications such as structural elements and films, these improved mechanical properties allow a reduction of the quantity of material in a specific product. As a result of the material reduction, the environmental impact of PP nanocomposite products can be expected to be lower than that of products made out of conventional material unless the 
production of the nanoparticles is accompanied by particularly high environmental impacts. The overall effect of nanocomposite products needs to be evaluated by means of a methodology that includes all of the steps of the life cycle: life cycle assessment (LCA).

Analogous to the environmental effects, a reduction in mass is also likely to affect the overall cost of nanocomposite products. Life cycle costing (LCC) is a methodology similar to LCA that allows the assessment of product costs throughout the life cycle.

Since this study deals with products that are still in the research or early production stage, a comprehensive evaluation of all environmental impacts and costs was not possible. Prospective forms of LCA and LCC can, however, be used to arrive at indicative results. These outcomes can then be used to make any necessary alterations in the production phase and to improve the efficiency of the processes.

The goal of the present study was to conduct prospective LCA and LCC of PP/layered silicate nanocomposite products. Three representative products were investigated: thin film for packaging, thick film for agricultural use, and injection-molded panels used in cars. Data from both the literature and industry were used to estimate the reduction in mass of the nanocomposite products, compare it to that of conventional products, and evaluate the environmental and cost (dis-)advantages. In 2003, Lloyd and Lave [5] studied nanocomposite automotive panels. We believed that we could significantly enhance their work using a different approach. Lloyd and Lave used steel and aluminum car panels as a reference, while we focused on PP panels. Both studies used Ashby material indices [6] to estimate mass reduction. However, our estimates for the Young modulus that are used in Ashby's material indices, were derived from experimental data, while Lloyd and Lave used an idealized model from Brune and Bicerano [7] that is subject to substantial uncertainty by assuming perfect adhesion between the clay platelets and the matrix. In the LCA part of the study, we used LCA databases (e.g., Ecoinvent) that are based on measured inputs and emissions of discrete industrial processes (e.g., per kg or MJ of product). Lloyd and Lave, in contrast, applied a hybrid method which derives environmental impacts from the economic output of the respective sector or subsector and is hence less accurate.

\section{Life Cycle Assessment (LCA)}

Methodology

\section{LCA Fundamentals}

Life cycle assessment (LCA) is a standardized method for the compilation and evaluation of the inputs, outputs, and potential environmental impacts of a product system throughout its life cycle. LCA methodology was standardized in 1997 by the International Standardization Organization (ISO) in their ISO-14040 series [8]. This standard distinguishes the following steps:

1. Goal definition and scoping. This step defines the purpose and the methodology of the LCA. Frequently, this is a comparison between two or more product alternatives. The product systems to be evaluated are defined together with the geographical and the temporal scopes. This phase also includes the definition of the functional unit, which then acts as a reference for the following steps. Finally, it determines which environmental impacts must be taken into account (the choice should be as comprehensive as possible).

2. Inventory analysis. In this phase, a flow diagram is developed and all energy and material requirements, emissions to air, water, and soil, and other environmental releases are quantified.

3. Impact assessment. This assessment determines the (potential) environmental impacts caused by the environmental releases analyzed in the inventory analysis.

4. Interpretation. In this final step, the results of the inventory analysis and the impact assessment are discussed, conclusions are drawn, and recommendations are made.

\section{Goal Definition and Scoping}

The purpose of the LCA in the present study was to investigate whether the use of a polypropylene nanocomposite has environmental advantages over the use of conventional polyolefins. To this end, we studied three product systems, namely packaging film, agricultural film, and automotive panels. The three conventionally produced products are all made of different materials: the packaging film is made out of neat PP, the agricultural film out of neat polyethylene (PE), and the automotive panels out of glass fiber-reinforced PP. A prospective LCA was performed (cradle-to-grave) that covers a wide range of environmental impacts. Using the LCA databases from SimaPro [9], we conducted an impact assessment on nonrenewable energy use (NREU), climate change (Global Warming Potential, $\mathrm{GWP}_{100}$ ), abiotic depletion, ozone layer depletion, photochemical oxidant formation, acidification, and eutrophication. We did not take into account human toxicity, terrestrial ecotoxicity, marine aquatic ecotoxicity, or fresh water aquatic ecotoxicity, because the existing methods do not yield comparable results and because they are incomplete with regard to the emissions studied [10]. 
Characteristics of the Functional Units. A functional unit was defined for each of the products studied. They are listed below together with the weights of the conventional products. The weights of the nanocomposite products are discussed in section "Weight Saving Using Nanocomposites".

Packaging film. As the functional unit, we chose the amount of packaging film needed for 1,000 bags of $200 \mathrm{~g}$ "Fruitfante" candies produced by Schuttelaar B.V. (Waddinxsveen, The Netherlands). The function of these bags is to provide sufficient physical protection and to act as a barrier in order to preserve the candies. Pure PP is the conventional material used to produce such a bag. We compared it with film produced from a PP nanocomposite.

Product characteristics of conventional packaging film:

- Weight of one bag: ${ }^{1} 3.66 \mathrm{E}-03 \mathrm{~kg}$

- Film requirement for functional unit: $3.66 \mathrm{~kg}$

Agricultural film. The functional unit is the amount of plastic film needed to cover a standard tomato greenhouse with a volume of approximately $650 \mathrm{~m}^{3}$. The purpose of this film is to provide thermal insulation and UV stability, combined with the necessary mechanical strength. We considered polyethylene (PE) to be the conventional material. It is compared with an agricultural film made out of a PP nanocomposite.

Product characteristics of conventional agricultural film:

- Film requirement for functional unit: ${ }^{2} 2.38 \mathrm{t}$.

Automotive panel. Body panels of a low-weight family car that runs $150,000 \mathrm{~km}$ during its entire lifetime were chosen as the functional unit. A PP-glass fiber composite was assumed to be the conventional material and is compared with panels produced from a PP nanocomposite.

Product characteristics of conventional body panels:

- Panel requirement for functional unit: $20 \mathrm{~kg}$ [13].

Weight Saving Using Nanocomposites. When a polymer (PP, PE) is blended with a nanoclay, the nanoclay silicate platelets exfoliate and bind with the polymer strands to form a nanoclay-polymer composite. This new nanocomposite structure exhibits improved material properties. The silicate layers have a labyrinthine effect on the diffusing gas and/or liquids, which leads to improved barrier properties. This makes nanocomposites an interesting class of materials for the packaging industry and for all applications in which low

\footnotetext{
${ }^{1}$ Weight of a packaging bag was based on: thickness of film $=6.00$ E-05 m; length of bag $=0.214 \mathrm{~m}$; width of bag $=0.157 \mathrm{~m}$; density of $\mathrm{PP}=0.91 \mathrm{t} / \mathrm{m}^{3} ; 2$ sheets per bag.

${ }^{2}$ Weight of agricultural film was based on: thickness of film $=$ $0.006 \mathrm{~m}$; length of greenhouse $=29.26 \mathrm{~m}$; width of greenhouse: $7.00 \mathrm{~m}$; width of greenhouse roof film $=8.00 \mathrm{~m}$; height of greenhouse $=2.44 \mathrm{~m}$; density of film $=0.92 \mathrm{t} / \mathrm{m}^{3}[11,12]$.
}

permeability is required. Moreover, the labyrinthine effect is supposedly involved in the improvement of fire-retardant properties [14]. Several studies have shown that mixing a polymer with nanoclay also improves its elasticity (Young modulus-E) and strength (tensile strength- $\sigma_{\mathrm{f}}$ ) [3, 15-21]. When material properties like barrier properties, strength, and elasticity improve, less material is needed to fulfill the same function. This means that the weight of the nanocomposite product will be lower than that of the conventional material.

In order to estimate the amount of nanocomposite material required for a given function, its properties must be compared with those of conventional materials. To do this, Ashby [6] defined material indices for different product functions (e.g., beam or panel) which have to comply with certain requirements, e.g., stiffness, strength, and tolerance to vibration. $\mathrm{He}$ based these material indices on material properties like the Young modulus $(\mathrm{E})$, tensile strength $\left(\sigma_{\mathrm{f}}\right)$, and density $(\rho)$. Using these indices, a nanocomposite material can be compared with conventional material with regard to mechanical properties. This allows estimation of material (weight) reduction. We chose the following equations from the various material indices distinguished by Ashby:

Packaging film and agricultural film: $\mathrm{M}=\sigma_{\mathrm{f}} / \rho$

We assumed:

- Strength-limited (the material should not tear)

- Tie (tearing is caused by a force parallel to surface of the film).

Automotive panels: $\mathrm{M}=\mathrm{E}^{1 / 3} / \rho$

We assumed:

- Stiffness-limited (the material should not bend, it should be stiff)

- Panel.

Ashby's material indices are inversely proportional to the amount of material needed for a given function: i.e., the higher the index, the less material is needed for the same function. Weight saving as a result of nanocomposite use can now be estimated.

For packaging film and agricultural film, weight saving was calculated using:

Change of weight $(\%)=\left(\frac{\sigma_{\mathrm{f}} / \rho[\text { conv }]}{\sigma_{\mathrm{f}} / \rho[\text { nano }]}-1\right) \cdot 100$

For automotive panels, weight saving was calculated using:

Change of weight $(\%)=\left(\frac{E^{1 / 3} / \rho[\text { conv }]}{E^{1 / 3} / \rho[\text { nano }]}-1\right) \cdot 100$

Ashby's method allows one to compare materials for a given purpose on the basis of their mechanical properties. 
When studying packaging film, this is not, however, the only aspect that must be taken into account. The barrier properties of this material are of major importance because the food that it envelops must be preserved. An additional index, therefore, is necessary: the oxygen transmission rate (OTR). This index reflects oxygen permeability. In order to have optimal properties, the OTR must be minimized. We estimated the material reduction due to the use of nanocomposite film by assuming that the thickness of the film is proportional to the OTR (the higher the OTR, the thicker the film must be). That is, we calculated the weight saving using:

Change of film thickness $(\mathrm{t}, \%)=\left(\frac{\text { OTR }[\text { nano }]}{\text { OTR }[\text { conv }]}-1\right) \cdot 100$

Change of weight $(\%)=\left(\frac{\left(\frac{\mathrm{t}}{100}+1\right) \cdot \rho[\text { nano }]}{\rho[\operatorname{conv}]}-1\right) \cdot 100$

The values for tensile strength $\left(\sigma_{\mathrm{f}}\right)$, Young modulus $(\mathrm{E})$, oxygen transmission rate (OTR), and specific weight $(\rho)$ used in this study are listed in Table 1.

Inserting these values in Eqs. 3-6 resulted in the estimates for weight saving listed in Table 2. Applying this weight reduction to the functional units based on conventional material yielded the weight of the products made with the polypropylene nanocomposite.

Table 2 shows that the weight-saving estimation for packaging film is $-17.5 \%$ based on OTR. However, because its mechanical properties $\left(\sigma_{\mathrm{f}}\right)$ do not allow a weight saving of this magnitude, the maximum weight saving for packaging film is $-9 \%$. This value was used in further calculations of packaging film. The weight saving for agricultural film is four times higher than for packaging film. This is caused by the large difference in tensile strength between the nanocomposite and low-density polyethylene (LDPE, conventional material used). The weight reduction for automotive panels is more or less negligible $(-1.25 \%)$. Although there is no improvement in the Young modulus when nanocomposites are used, there is a large improvement in density. The lower density is also the reason for the weight reduction. Calculating weight savings by hand using the values in Table 1 gave slightly different values than reported in Table 2. This was due to rounding-off errors.

Inventory Analysis

\section{The Life Cycle Figure}

Figure 1 shows the process chain for the production of polypropylene nanocomposite products, i.e., packaging film, agricultural film, and automotive panels. To the authors' knowledge, the production process shown in the figure has not yet been operated on a commercial scale. Since we studied the process in an early stage, there is room for optimization. In fact, our assumptions may be too conservative, i.e., more substantial progress than assumed might be possible with regard to material properties (see below). Moreover, other process configurations, possibly involving other types of nanoparticles, may turn out to be more attractive.

The life cycle process of a nanocomposite comprises five major steps: the preparation of the nanoclay, the preparation of polypropylene, the mix/dilution step, the use phase, and the waste treatment phase. In the nanoclay part of the process, raw clay (Ca-bentonite) is extracted and

Table 1 Parameter values (LDPE: Low-density polyethylene, Nanocomp: Nanocomposite, PP/GF comp: Polypropylene/glass fiber composite)

\begin{tabular}{|c|c|c|c|}
\hline Parameter & Value & Unit & Reference \\
\hline$\sigma_{\mathrm{f}}-\mathrm{PP}$ & 33.5 & $\mathrm{MPa}$ & {$[22]$} \\
\hline$\sigma_{\mathrm{f}}-\mathrm{LDPE}$ & 24 & $\mathrm{MPa}$ & {$[12]$} \\
\hline$\sigma_{\mathrm{f}}-$ nanocomp $3 \%$ clay (for packaging film and agricultural film) & 37.4 & MPa & {$[22]$} \\
\hline E-PP/GF comp (30\% GF) & 5.76 & $\mathrm{GPa}$ & {$[23]$} \\
\hline E-nanocomp 5\% clay (for automotive panels) & 1.8 & $\mathrm{GPa}$ & {$[22,23]$} \\
\hline OTR-PP & 95 & $(\mathrm{cc} \mathrm{mm}) /\left(\mathrm{m}^{2} 24 \mathrm{~h} 1 \mathrm{Atm}\right)$ & {$[23]$} \\
\hline OTR-nanocomp $3 \%$ clay & 76.9 & $(\mathrm{cc} \mathrm{mm}) /\left(\mathrm{m}^{2} 24 \mathrm{~h} 1 \mathrm{Atm}\right)$ & Expert estimation and [23] \\
\hline$\rho-\mathrm{PP}$ & 0.91 & $\mathrm{t} / \mathrm{m}^{3}$ & \\
\hline$\rho-\mathrm{LDPE}$ & 0.923 & $\mathrm{t} / \mathrm{m}^{3}$ & \\
\hline$\rho$ —nanocomp $3 \%$ clay & 0.928 & $\mathrm{t} / \mathrm{m}^{3}$ & \\
\hline$\rho$-nanocomp 5\% clay & 0.94 & $\mathrm{t} / \mathrm{m}^{3}$ & \\
\hline$\rho$-PP/GF comp & 1.402 & $\mathrm{t} / \mathrm{m}^{3}$ & \\
\hline
\end{tabular}


Table 2 Estimated weight saving when polymer nanocomposites are used

\begin{tabular}{|c|c|c|c|c|}
\hline & $\begin{array}{l}\text { Weight of functional } \\
\text { unit with conventional } \\
\text { material }\end{array}$ & $\begin{array}{l}\text { Weight saving } \\
(\%)\end{array}$ & $\begin{array}{l}\text { Formula } \\
\text { used }\end{array}$ & $\begin{array}{l}\text { Weight of functional } \\
\text { unit with nanocomposite }\end{array}$ \\
\hline Packaging film, based on OTR & $3.66 \mathrm{~kg}$ & -17.5 & Eq. 6 & $3.02 \mathrm{~kg}$ \\
\hline Packaging film, based on mechan. properties & $3.66 \mathrm{~kg}$ & -9 & Eq. 3 & $3.33 \mathrm{~kg}$ \\
\hline Agricultural film & $2.38 \mathrm{t}$ & -36.5 & Eq. 3 & $1.51 \mathrm{t}$ \\
\hline Automotive panels & $20.00 \mathrm{~kg}$ & -1.25 & Eq. 4 & $19.75 \mathrm{~kg}$ \\
\hline
\end{tabular}

Fig. 1 Process chain for the production and use of polypropylene nanocomposite products

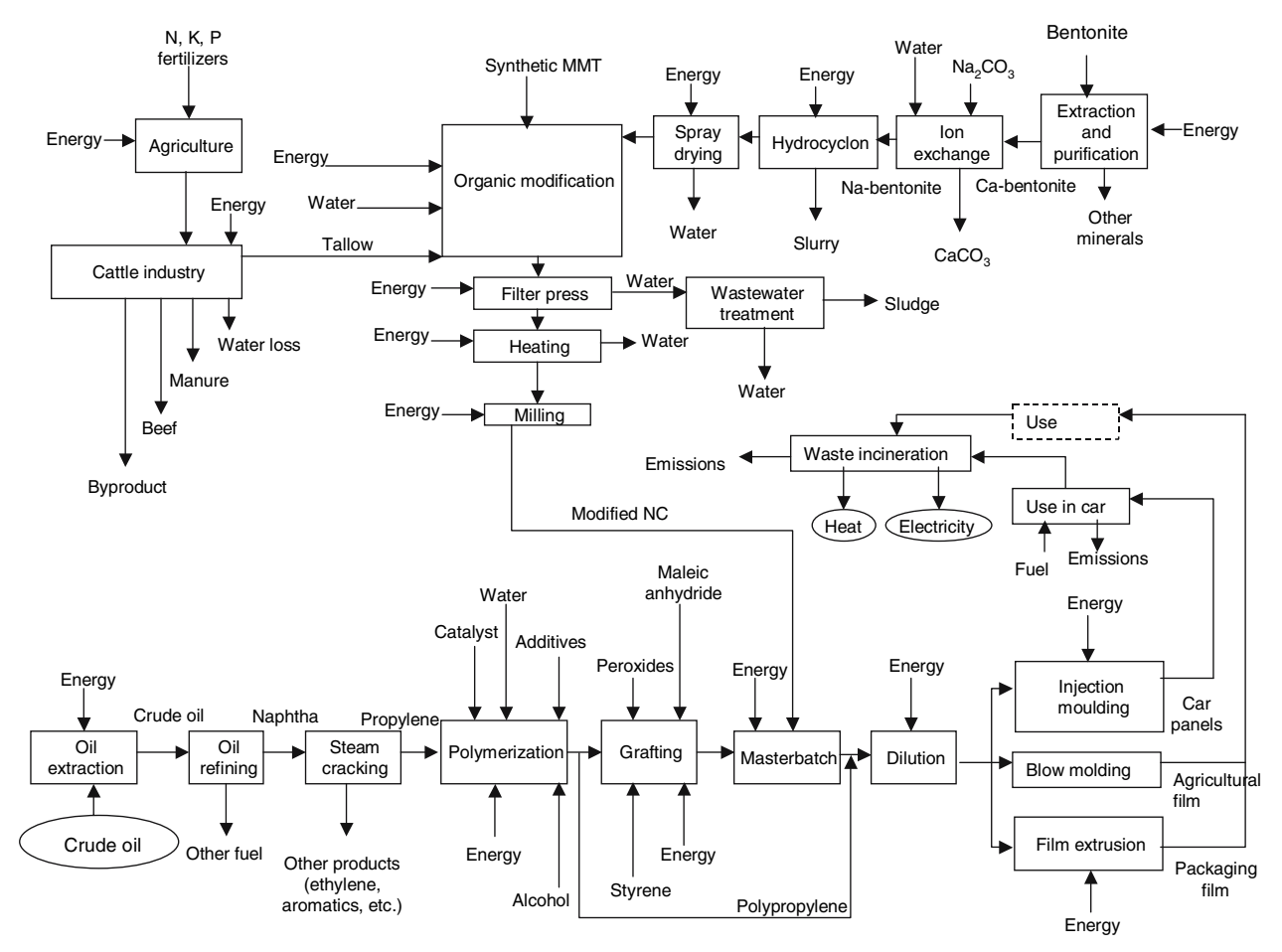

subjected to an ion exchange to replace divalent calcium ions with monovalent sodium ions. This results in an increase in the interlayer distance between the clay platelets. After separation ("hydrocyclone") and a drying step ("spray drying"), another ion exchange is performed ("organic modification") in which sodium ions are replaced by alkyl quaternary ammonium salts (delivered by tallow), which increases the interlayer distance even more. The distance between the platelets is a crucial factor during composite preparation since it helps achieve a sufficient degree of dispersion of the nanoclay in the PP matrix. This dispersion is accomplished during the preparation of the so-called masterbatch in an extruder (the shearing force applied leads to dispersion) after the clay particles have been filtered ("filter press"), dried ("heating"), and ground to reduce particle size to about $30 \mu \mathrm{m}$ ("milling").

The preparation of polypropylene starts with crude oil. Crude oil is refined after its extraction and one of the products is naphtha, which is steam-cracked. One of the main outputs of this steam-cracking process is propylene, which is then polymerized to polypropylene.

In the mix/dilution step the polypropylene is first grafted with maleic anhydride. This compound acts as a compatibilizer that helps blend the polypropylene and the clay, and lead to better mechanical properties $[15,18]$. Then, in the masterbatch, the grafted polypropylene is mixed with the modified nanoclay to obtain the nanocomposite. To acquire the desirable nanoclay concentration, extra polypropylene is added in the dilution step. The final product is achieved by either film extrusion (packaging film), blow molding (agricultural film), or injection molding (automotive panel).

The next step of the life cycle is the use phase. In the case of automotive panels, the use phase allows for the amount of fuel that is combusted in a car based on the weight of the panels. The nanocomposite automotive panel is lighter in weight than the conventional panel and therefore results in lower petrol consumption in the use 
phase and therefore lower emissions. There are no analogous considerations for packaging films and agricultural films. Because the conditions in the use phase for both the nanocomposite and the conventional products are identical, the use phase was not considered in the LCA. The final step of the life cycle is waste treatment. We assumed that, after disposal, the products are burned in a waste incinerator in which part of the released energy (the reaction is exothermic) is recovered for the generation of heat and power.

\section{Life Cycle Inventory Data}

Table 3 presents an overview of the material and energy inputs needed for nanocomposite production and the use phase. Data for product forming are given separately in Table 7. Tables 4-6 show the energy and material requirements of the products in more detail (per tonne product). The values for film represent the input data for both packaging and agricultural film (identical assumptions). Data for PP came from APME Ecoprofiles [24], while data on the production of nanoclay (Table 4) and nanocomposite (Table 5) were provided by the Institute for Polymer Research (IPF, Dresden, Germany). The latter energy and material data came from a pilot plant that produces polypropylene/nanoclay-composite film. The amount of electricity needed for extrusion (used for grafting, masterbatch, dilution, and glass fiber/polypropylene composite production) was estimated from data from the Energy Efficiency Office [25]. The energy and material inputs for the production of polypropylene-glass fiber composite are listed in Table 6. The material requirements were taken from Qiu et al. [26]. Silane-grafted polypropylene (PP-g-Si) was replaced by maleic anhydride-grafted polypropylene (PP-g-Ma, as for nanocomposite) because better life cycle inventory data were available for the latter compound. Table 7 lists the inputs for the production of the final products.

All of the nanocomposite products are produced from polypropylene nanocomposites and processed the same way as the conventional products.

When an automotive panel is used in a car, part of the car fuel use and the emissions can be assigned to the panel. We used the following data for our environmental and economic assessment:

- Weight of the car without panels: 1,222 kg (including 1.6 passengers, which is an average)

- Weight of polypropylene-glass fiber panels: $20 \mathrm{~kg}$

- Weight of nanocomposite panels: $19.75 \mathrm{~kg}(1.25 \%$ weight reduction)

- Droven distance in life of the car: 150,000 km

- Fuel use during the life of the car $(150,000 \mathrm{~km})$ with PP/GF panels: $9915.0 \mathrm{~kg}$ [28]
- Fuel use during the life of the car $(150,000 \mathrm{~km})$ with nanocomposite panels: ${ }^{3} 9,913.6 \mathrm{~kg}$

- Fuel use assigned to PP/GF panels: $1-\left(\frac{1242}{1222}\right)^{-0.72} \cdot 9,915.0 \mathrm{~kg}=115.2 \mathrm{~kg}$ fuel

- Fuel use assigned to the conventional panels: $5.7609 \mathrm{t}$ fuel/t panel

- Fuel use assigned to nanocomposite panels (analogous to $\mathrm{PP} / \mathrm{GF}$ panels): $5.7610 \mathrm{t}$ fuel/t panel.

After use, the products are disposed of in a waste incinerator. Energy is released during waste incineration. It is assumed that for every joule of waste (calorific value), 0.12 joules of electricity and 0.12 joules of heat are regained [29]. The calorific values of the products (the waste fractions) are listed in Table 8 .

Using the material inputs from Tables 4-6 yields the energy credits listed in Table 9. Note that they are valued negatively because electricity and heat are produced and the impacts of conventionally generated electricity and heat are avoided. (A representative mix of European electricity was obtained using the weighed average of UCTE, NORDEL, and CENTREL electricity. See Table 10.)

The incineration process produces not only energy credits, but also emissions. These were taken into account using data from Doka ${ }^{4}$ [30] (see Table 10).

The impact assessment of all the material and energy inputs and outputs listed above was calculated using SimaPro 7 software and the data sources listed in Table 10.

\section{Results: Life Cycle Impact Assessment}

The life cycle impact assessment was carried out using the impact categories defined by Guinée et al. [38] and the non-renewable energy use (NREU; this is total fossil and nuclear energy). The results are presented in Table 11 and Figs. 2-4. Note that relative results have been included in the figures and that they represent the difference between the conventional product and the nanocomposite product. This form of presentation was chosen, because the different units of the impact categories make it impossible to show absolute results in one graph.

Figure 2 shows that both product alternatives are more or less equal for all but the ozone layer-depletion impact (the differences are less than 6\%). The impact of the ozone layer depletion differs from those of the other impacts in that it is negative. The reason for this is that the credits from waste incineration outbalance the impacts

\footnotetext{
$\overline{3}$ According to Sedan equation: $f_{2}=f_{1} \cdot\left(\frac{W_{1}}{W_{2}}\right)^{0.72}$, where $f=$ car efficiency $(\mathrm{km} / \mathrm{kg}$ fuel) and $W=$ weight of the car.

${ }^{4}$ Doka [30] assumes $15.9 \%$ water in the polymer waste. We corrected for this assuming $100 \%$ PP.
} 
Table 3 Energy and material inputs for production and use of products (f.u.: functional unit, nanocomp.: nanocomposite, conv.: conventional material)

\begin{tabular}{|c|c|c|c|c|c|c|c|}
\hline \multirow[t]{2}{*}{ Input } & \multirow[t]{2}{*}{ Unit } & \multicolumn{2}{|c|}{ Packaging film } & \multicolumn{2}{|c|}{ Agricultural film } & \multicolumn{2}{|c|}{ Automotive panel } \\
\hline & & $\begin{array}{l}\text { Nanocomp. } \\
\text { f.u.: } 3.33 \mathrm{~kg}\end{array}$ & $\begin{array}{l}\text { Conv. } \\
\text { f.u.: } 3.66 \mathrm{~kg}\end{array}$ & $\begin{array}{l}\text { Nanocomp. } \\
\text { f.u.: } 1,510 \mathrm{~kg}\end{array}$ & $\begin{array}{l}\text { Conv. } \\
\text { f.u.: } 2380 \mathrm{~kg}\end{array}$ & $\begin{array}{l}\text { Nanocomp. } \\
\text { f.u.: } 19.75 \mathrm{~kg}\end{array}$ & $\begin{array}{l}\text { Conv. } \\
\text { f.u.: } 20.0 \mathrm{~kg}\end{array}$ \\
\hline Polypropylene & $\mathrm{kg}$ & 3.21 & 3.66 & 1457 & - & 18.6 & - \\
\hline Polyethylene & $\mathrm{kg}$ & - & - & - & 2380 & - & - \\
\hline PP/GF composite & $\mathrm{kg}$ & - & - & - & - & - & 20.0 \\
\hline Nanoclay & $\mathrm{kg}$ & 0.1 & - & 45.3 & - & 0.99 & - \\
\hline Styrene & $\mathrm{kg}$ & 0.01 & - & 4.53 & - & 0.099 & - \\
\hline Maleic anhydride & $\mathrm{kg}$ & 0.005 & - & 2.27 & - & 0.049 & - \\
\hline Electricity for nanoclay production & MJ & 2.12 & - & 963.5 & - & 21.01 & - \\
\hline Fuel oil for nanoclay & $\mathrm{kg}$ & 0.010 & - & 4.68 & - & 0.10 & - \\
\hline Electricity for nanocomposite production & MJ & 9.1 & - & 4146 & - & 57.2 & - \\
\hline Fuel & $\mathrm{kg}$ & - & - & - & - & 113.8 & 115.2 \\
\hline
\end{tabular}

Table 4 Energy and material inputs for the production of nanoclay for 1 tonne of film and 1 tonne of panels
Table 5 Energy and material inputs for the production of 1 tonne of nanocomposite for film and 1 tonne of nanocomposite for panel (without production of nanoclay—see Table 4)

\begin{tabular}{llll}
\hline $\begin{array}{l}\text { Inputs for production } \\
\text { of nanoclay }\end{array}$ & Unit & $\begin{array}{l}\text { Amount for 1 tonne } \\
\text { of film }\end{array}$ & $\begin{array}{l}\text { Amount for 1 tonne } \\
\text { of panel }\end{array}$ \\
\hline $\begin{array}{l}\text { Bentonite } \\
\text { Soda }\end{array}$ & $\begin{array}{l}\text { tonne } \\
\text { tonne }\end{array}$ & 0.0195 & 0.0325 \\
Tallow & tonne & 0.0105 & 0.0032 \\
Fuel oil & & & 0.0175 \\
$\quad$ For spray drying & $\mathrm{kg}$ & 3.1 & 5.17 \\
Electricity & & & \\
For ion exchange & $\mathrm{MJ}_{\mathrm{e}}$ & 0 & 0 \\
$\quad$ For hydrocyclone & $\mathrm{MJ}_{\mathrm{e}}$ & 18.7 & 31.2 \\
$\quad$ For spray drying & $\mathrm{MJ}_{\mathrm{e}}$ & 7.66 & 12.7 \\
$\quad$ For organic modification & $\mathrm{MJ}_{\mathrm{e}}$ & 442 & 737 \\
For filter press & $\mathrm{MJ}_{\mathrm{e}}$ & 2.2 & 3.67 \\
For heating & $\mathrm{MJ}_{\mathrm{e}}$ & 152.1 & 253.6 \\
For milling & $\mathrm{MJ}_{\mathrm{e}}$ & 15.42 & 25.7 \\
\hline
\end{tabular}

\begin{tabular}{llll}
\hline $\begin{array}{l}\text { Inputs for production of } \\
\text { nanocomposite }\end{array}$ & Unit & $\begin{array}{l}\text { Amount for } \\
1 \text { tonne of film }\end{array}$ & $\begin{array}{l}\text { Amount for } \\
1 \text { tonne of panel }\end{array}$ \\
\hline $\begin{array}{llll}\text { Polypropylene resin } \\
\text { For grafting }\end{array}$ & tonne & 0.025 & 0.042 \\
$\quad$ For dilution & tonne & 0.94 & 0.90 \\
Maleic anhydride & tonne & 0.0015 & 0.0025 \\
Styrene & tonne & 0.003 & 0.005 \\
Peroxides & tonne & 0.0006 & 0.001 \\
Electricity & & & 126 \\
$\quad$ For grafting & $\mathrm{MJ}_{\mathrm{e}}$ & 75.6 & 252 \\
For masterbatch & $\mathrm{MJ}_{\mathrm{e}}$ & 151.2 & 2520 \\
For dilution & $\mathrm{MJ}_{\mathrm{e}}$ & 2520 & \\
\hline
\end{tabular}

of the other life cycle stages. Due to its lower PP content, the nanocomposite packaging film has fewer credits than the conventional product. One can conclude, therefore, that the conventional product is somewhat better for the environment with regard to the ozone layer depletion impact. 
Table 6 Energy and material inputs for the production of 1 tonne polypropylene-glass fiber composite (the electricity requirements cover the grafting of PP and the extrusion needed to produce the composite)

\begin{tabular}{lll}
\hline $\begin{array}{l}\text { Inputs for production of } \\
\text { polypropylene-glass fiber composite }\end{array}$ & Unit & $\begin{array}{l}\text { Amount for } \\
1 \text { tonne of panel }\end{array}$ \\
\hline Polypropylene resin & t & 0.688 \\
Maleic anhydride & $\mathrm{t}$ & 0.0035 \\
Styrene & $\mathrm{t}$ & 0.007 \\
Peroxides & $\mathrm{t}$ & 0.0014 \\
Glass fiber & $\mathrm{t}$ & 0.3 \\
Electricity & $\mathrm{MJ}_{\mathrm{e}}$ & 2696.4 \\
\hline
\end{tabular}

Table 7 Inputs for the production of the products

\begin{tabular}{|c|c|c|c|c|}
\hline Product & Inputs for the production of the products & Unit & $\begin{array}{l}\text { Amount for } 1 \text { tonne } \\
\text { of product }\end{array}$ & Reference \\
\hline Packaging film—conventional & Polypropylene-oriented film & tonne & 1.0 & {$[24]$} \\
\hline Agricultural film—conventional & Low-density polyethylene film & tonne & 1.0 & {$[24]$} \\
\hline \multirow[t]{2}{*}{ Automotive panel—conventional } & Polypropylene-glass fiber composite & tonne & 1.0 & {$[26]$} \\
\hline & Injection molding-Electricity & $\mathrm{GJ}_{\mathrm{e}}$ & 9.11 & $\begin{array}{l}\text { (According to [27], but excluding } \\
\text { space heating) }\end{array}$ \\
\hline
\end{tabular}

Table 8 Calorific values (higher heating values) of the waste fractions

\begin{tabular}{ll}
\hline Material & $\begin{array}{l}\text { Calorific value (higher } \\
\text { heating value) (GJ/tonne) }\end{array}$ \\
\hline PP & 48.9 \\
PE & 50.3 \\
Tallow & 41.88 \\
\hline
\end{tabular}

Table 9 Energy credits from product incineration

\begin{tabular}{lll}
\hline Product & $\begin{array}{l}\text { Electricity } \\
\text { (GJ/tonne) }\end{array}$ & $\begin{array}{l}\text { Heat } \\
\text { (GJ/tonne) }\end{array}$ \\
\hline Nanocomposite packaging film & -5.71 & -5.71 \\
Conventional packaging film & -5.87 & -5.87 \\
Nanocomposite agricultural film & -5.71 & -5.71 \\
Conventional agricultural film & -6.04 & -6.04 \\
Nanocomposite automotive panel & -5.61 & -5.61 \\
Conventional automotive panel & -4.04 & -4.04 \\
\hline
\end{tabular}

Figure 3 shows that nanocomposite agricultural film has a lower impact for most of the categories. With regard to photochemical oxidant formation, however, the impact of the nanocomposite is somewhat higher. Credits with regard to waste incineration are higher for the conventional product than for the nanocomposite (due to the higher weight of the conventional product). Nonetheless, the overall conclusion is that the nanocomposite performs
Table 10 Input and output references

\begin{tabular}{lc}
\hline & Data source \\
\hline Input & \\
Bentonite & {$[31]$} \\
Soda & {$[32]$} \\
Tallow & {$[33]$} \\
PP resin & {$[24]$} \\
Glass fiber & {$[34]$} \\
Maleic anhydride & {$[32]$} \\
Styrene & {$[27]$} \\
Natural gas & {$[35]$} \\
Electricity: weighed average of 74.4\% & {$[36]$} \\
$\quad$ UCTE Electricity, 15.1\% NORDEL & \\
$\quad$ Electricity, and 10.5\% CENTREL & \\
$\quad$ Electricity (All medium voltage) & \\
Fuel oil & {$[37]$} \\
Fuel combustion in use phase & {$[28]$} \\
Polypropylene incineration & {$[30]$} \\
Polyethylene incineration & {$[30]$} \\
Output & \\
Heat (natural gas) & {$[35]$} \\
Electricity (as above) & {$[36]$} \\
\hline
\end{tabular}

better in environmental terms than the conventional product.

It can be concluded from Fig. 4 that both product alternatives of automotive panels perform more or less equally for all impacts (between $-3.5 \%$ and $+0.5 \%$ difference). 
Table 11 Impact results for nanocomposite and conventional packaging film, agricultural film, and automotive panels

\begin{tabular}{|c|c|c|c|c|c|c|c|}
\hline \multirow[t]{2}{*}{ Impact category } & \multirow[t]{2}{*}{ Unit } & \multicolumn{2}{|c|}{ Packaging film } & \multicolumn{2}{|c|}{ Agricultural film } & \multicolumn{2}{|c|}{ Automotive panel } \\
\hline & & Nanocomp & Conventional & Nanocomp & Conventional & Nanocomp & Conventional \\
\hline NREU & GJ & 0.284 & 0.283 & 107.1 & 155.9 & 8.21 & 8.23 \\
\hline Climate change & $\mathrm{kg} \mathrm{CO}_{2}$-eq & 15.7 & 15.9 & 5642 & 9242 & 570 & 569 \\
\hline Abiotic depletion & $\mathrm{kg} \mathrm{Sb-eq}$ & 0.135 & 0.139 & 52.8 & 79.4 & 3.62 & 3.60 \\
\hline Ozone layer depletion & kg CFC-11-eq & $-1.83 \mathrm{E}-7$ & $-2.81 \mathrm{E}-7$ & $-8.32 \mathrm{E}-5$ & $-1.88 \mathrm{E}-4$ & $5.34 \mathrm{E}-5$ & $5.54 \mathrm{E}-5$ \\
\hline Photochem oxidant form & $\mathrm{kg}$ ethene & $3.83 \mathrm{E}-3$ & $3.88 \mathrm{E}-3$ & 1.21 & 1.16 & 0.587 & 0.595 \\
\hline Acidification & $\mathrm{kg} \mathrm{SO}_{2}$-eq & 0.116 & 0.12 & 36.5 & 38.7 & 2.33 & 2.36 \\
\hline Eutrophication & $\mathrm{kg} \mathrm{PO}_{4}^{3-}$-eq & $8.62 \mathrm{E}-3$ & $9.19 \mathrm{E}-3$ & 2.78 & 4.37 & 0.338 & 0.340 \\
\hline
\end{tabular}

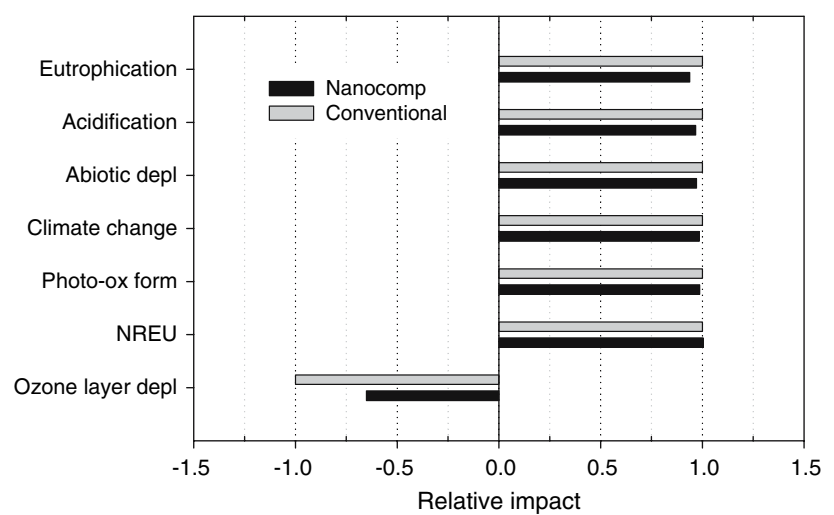

Fig. 2 Relative results of the impact assessment of packaging film

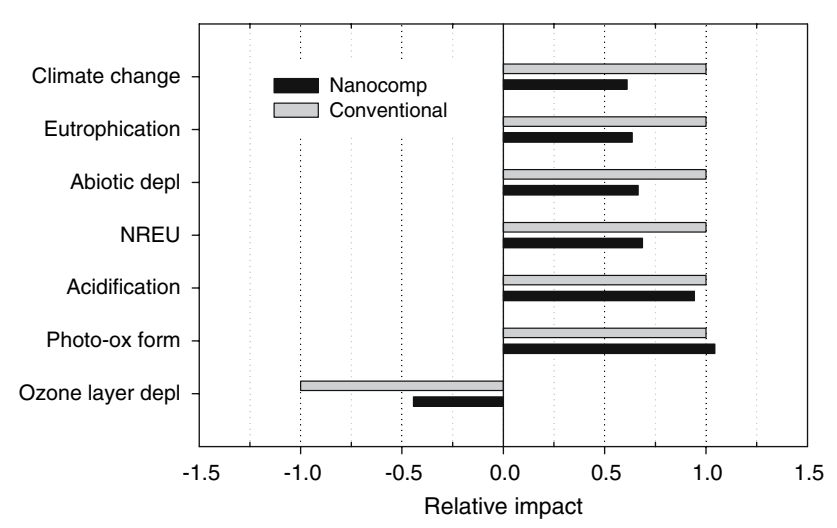

Fig. 3 Relative results of the impact assessment of agricultural film

Discussion and Conclusions: Life Cycle Interpretation

The main differences in life cycle impact between conventionally produced products and products made from a polypropylene nanocomposite could be the result of (1) the production of nanoclay in the nanocomposite products and (2) the reduced weight of the nanocomposite products.

Although the use of nanoclay in nanocomposite products might be expected to cause a major difference, it is

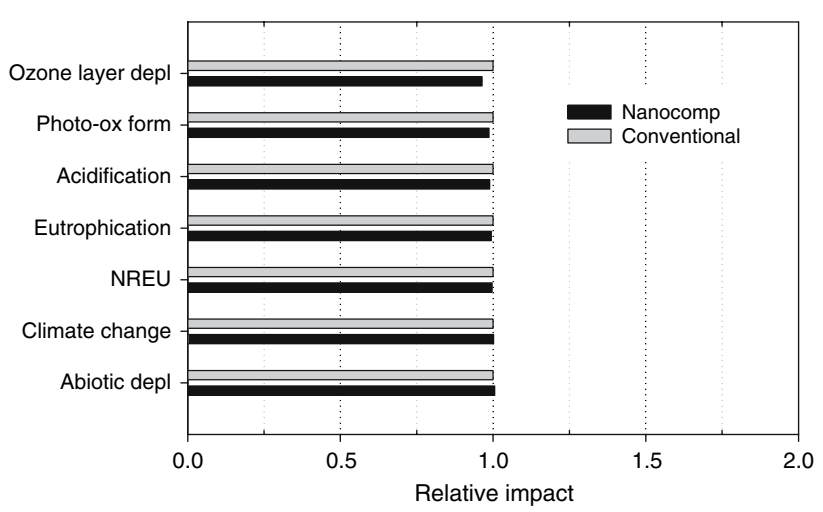

Fig. 4 Relative results of the impact assessment of automotive panels

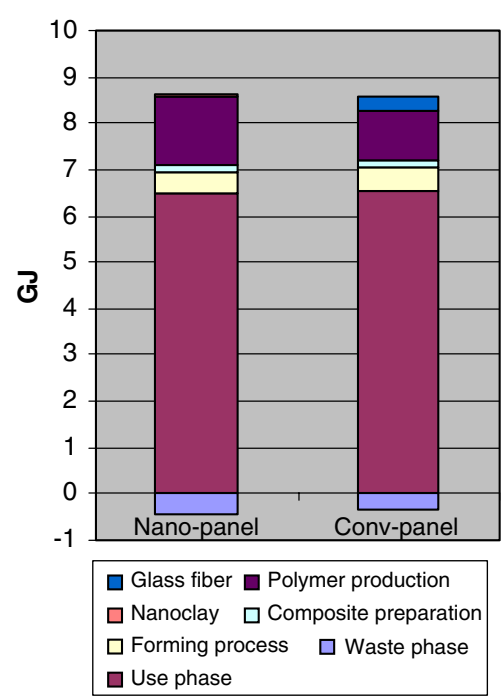

Fig. 5 NREU of one functional unit of automotive panels (cradle-tograve)

generally of minor importance due to the very low clay load of the composites. The fact that uncertainties in life cycle inventory (LCI) data of nanoclay production are high (they are based on estimates and pilot plant laboratory data) 


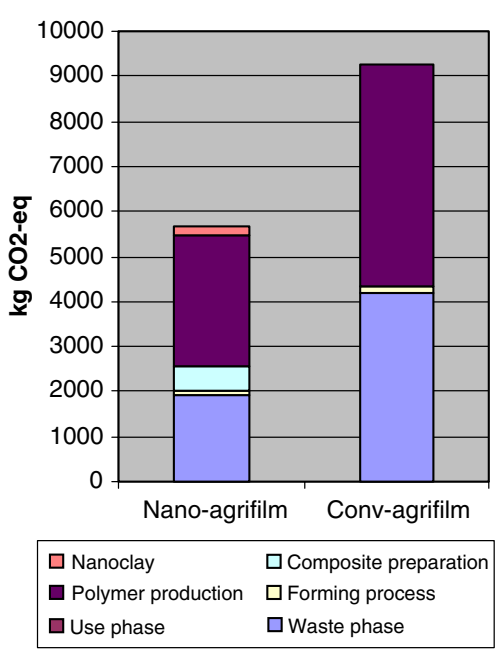

Fig. $6 \mathrm{GWP}_{100}$ of one functional unit of agricultural film (cradle-tograve)

does not, therefore, impair the robustness of the results. The real impacts of nanoclay production are probably even lower than estimated in this study, because the energy use in the pilot plant considered here is probably higher than the energy use in commercial-scale industrial plants.

Besides the nanoclay production, further impacts are related to composite preparation, polymer production, product forming, waste incineration, and, in the case of automotive panels, fuel combustion in the use phase. Overall, fuel consumption and combustion in the use phase is an important contributor to the life cycle impacts of the automotive panel. Figure 5 shows that, with respect to nonrenewable energy use, fuel consumption is the main contributor. The same holds for the other impacts, where the consumption and combustion of fuel are dominant over the other lifecycle stages.

The estimated weight reduction was highest for agricultural film, namely $-36.5 \%$. Figure 6 shows that this results in a clearly lower environmental impact of the nanocomposite.

Data on polypropylene and polyethylene production, oriented film production, and film extrusion were taken from APME Ecoprofiles [24]. These data, from industrial plants, were gathered in the early 1990s and are, therefore, somewhat dated. Although more recent (2005) data have been made available by this research group [27], the 2000 data [24] have a much higher level of detail, especially for lower material inputs and emissions. Because this enables a more precise impact assessment, data from the 2000 publication [24] were used in the present study. A general comparison between the processes described in the two APME Ecoprofiles studies [24, 27] showed that the contribution to non-renewable energy use decreased by around $3 \%$ and that the contribution to $\mathrm{GWP}_{100}$ has not changed in the last years. It is plausible, therefore, that the old data still give a good estimate of the present environmental impacts of polymer production and product forming and that there have only been marginal improvements in the last years.

With respect to the CML 2 baseline 2000 method [38], it should be emphasized that not all inventory data were converted to impact. This is due to incomplete coverage of the method as a result of knowledge gaps. In fact, there are important information gaps, especially with regard to toxicity (eco- and human), and the outcome depends strongly on the method used. These toxicity impacts, therefore, were excluded from the present study (they are not incorporated in Figs. 2-4). Methods for determining the (eco)toxicological impacts of products are, however, improving; for example, progress was reported in the LCA project OMNIITOX [39, 40]. Impacts are considered to be more precise for NREU and climate change, because the entry commodities from which they are calculated are considerably less than for toxicity and because they can easily be derived from measured data (e.g., from metered power use).

The main reason nanocomposite product alternatives are expected to have lower environmental impacts is because less material is needed for the same function. The method we used to estimate weight reduction, however, is subject to uncertainty. Important questions to be raised are: (1) Does the application of Ashby's method lead to sufficiently accurate results for the products under consideration? (2) If so, what are the best estimates for the material properties $\mathrm{E}$ and $\sigma$ ? These questions will be dealt with in the following paragraphs.

The use of Ashby's material indices for the environmental assessment of nanocomposites was first applied by Lloyd and Lave [5], who used them to estimate the weight reduction of nanocomposite automotive panels. We used the same formula in the present study: $M=E^{1 / 3} / \rho$. This formula was derived from the assumption that panels are stiffness-limited. However, also with respect to packaging and agricultural films, which are assumed to be strengthlimited, the Ashby indices provide just a preliminary analysis. A thorough study is required for a more accurate estimate.

Many investigations have reported different values for $\mathrm{E}$ and $\sigma$. Our estimations of the two properties are uncertain as well. We used data from Svoboda et al. [22], who reported a smaller increment in $\mathrm{E}$ and $\sigma$ when using nanocomposites than did, for example, Kretzschmar et al. [17] and Oya et al. [19]. Kretzschmar's group [17] used neat PP with a very low value for $\mathrm{E}$ and $\sigma$. The beneficial effect of adding nanoparticles is known to be more pronounced for this type of material, i.e., the increase in $\mathrm{E}$ and $\sigma$ is higher. Based on personal communication from experts in the field, however, we believe that a small increase in $\mathrm{E}$ 
and $\sigma$ is more realistic. Whatever the case, our approach leaves room for the possibility that our weight-reduction estimate is too pessimistic and that the advantages of using nanocomposites are better than what we report here.

We assumed the uncertainty to be smaller for agricultural film because the $\sigma$ value of polyethylene came from a greenhouse film supplier [12] and the value of the nanocomposite was in line with other sources.

There was a large variation among the data sources with respect to the oxygen transmission rate (OTR). We used field data in combination with data from MatWeb [23] to study this factor. According to our calculations, the limiting factor for weight reduction comprises mechanical not barrier properties. The uncertainties with regard to the oxygen transmission rate, therefore, are less relevant as long as the mechanical properties are the limiting factor.

Using the assumptions we made in this study, we were able to conclude that the use of a polypropylene nanocomposite can have clear environmental advantages over conventional material in certain cases.

- Our results were best for agricultural film since the use of a nanocomposite showed a lower impact for five out of seven environmental categories. This was the result of the high weight saving.

- The impact of the nanocomposite on packaging film was similar to that of neat polypropylene. The nanocomposite did, however, have a higher impact on ozone-layer depletion.

- The nanocomposite automotive panel and conventional automotive panel performed equally well.

\section{Effect of Free Nanoparticles}

Nanoparticles can be released into the atmosphere during the manufacture, use, and disposal of engineered nanomaterials and can thus end up in the environment or come in contact with humans. The effects that they might have are not yet fully understood, although research on the topic is underway. It is unfortunate that there is only some general knowledge currently available on fine particles since the specific size and shape of the particles determine the real danger for man and the environment [41-43].

The risks that nanoparticles form for the environment, and indirectly for human health, are determined by their toxicity, persistence in the environment, and bioaccumulation. In general, humans can uptake nanoparticles by means of inhalation, ingestion, or, in some cases, absorption through the skin. When nanoparticles are inhaled, they can affect the human body in two major ways: (1) they can induce inflammation of the respiratory tract and cause tissue damage and subsequent systemic effects or (2) they can be transported through the bloodstream to other vital organs or tissues in the body where they may cause cardiovascular and extrapulmonary complications. Normally, uptake via the skin rarely occurs although the risk may be higher for individuals whose skin is damaged by, for example, the sun or eczema. Penetration through the skin can lead to cell damage, since nanoparticles can facilitate the production of reactive molecules.

The composition, size, and surface characteristics of the nanoparticles determine their distribution in the body. Durable, biopersistent nanoparticles may accumulate in the body, in particular in the lungs, brain, and liver. More research is required on the mobility of different types of nanoparticles [42].

\section{Life Cycle Costing (LCC)}

\section{Methodology}

In contrast to LCA methodology, life cycle costing (LCC) has not yet been standardized. The Society for Environmental Toxicity and Chemistry (SETAC) is, however, currently working on the matter [44]. Like those described above for LCA, the following phases can be defined for LCC:

- Goal and scope definition

- Cost calculations

- Interpretation of the results.

\section{Goal and Scope Definition}

Although the focus is on economic aspects, the goal and scope of the LCC in this study are similar to those of the environmental assessment reported in the first part of the article. The coverage is also cradle-to-grave.

\section{Cost Calculations}

The costs of manufacturing the products under consideration were estimated using the market prices of all material and energy inputs. The relevant inputs are listed in Table 3. Peroxides were not taken into account due to a lack of price data. Moreover, the amount of peroxides in the final product is negligible (no more than $0.1 \%$ ).

Life cycle costs were calculated from the material and energy inputs and their costs. Note that the prices vary over the years and differ per source. The price of polypropylene, for example, is closely correlated to that of crude oil due to the use of oil-based feedstocks, the process energy 
Table 12 Price estimates for material and energy inputs in the life cycle of the products

\begin{tabular}{|c|c|c|c|c|}
\hline & Low price & High price & Unit & Source \\
\hline Nanoclay & 4400 & 10000 & $€ /$ tonne & $\begin{array}{l}\text { [5] and personal communication with } \\
\text { Crystal Nanoclay and Süd Chemie }\end{array}$ \\
\hline Polypropylene & 787 & 1191 & $€ /$ tonne & Industry sources \\
\hline Polyethylene & 926 & 1401 & $€ /$ tonne & Industry sources \\
\hline GF/PP composite & 1550 & 2000 & $€ /$ tonne & {$[45]$} \\
\hline Styrene & 1060 & 1604 & $€ /$ tonne & Industry sources \\
\hline Maleic anhydride & 694 & 1050 & $€ /$ tonne & Industry sources \\
\hline Electricity & 18.3 & - & $€ /$ tonne & [46] \\
\hline Car fuel & 1.82 & - & $€ / \mathrm{kg}$ & Price in March 2007 in $\mathrm{NL}^{\mathrm{a}}$ \\
\hline Incineration & 100 & - & $€ /$ tonne & {$[47]$} \\
\hline
\end{tabular}

${ }^{a}$ This price is the weighted average of $19 \mathrm{wt} \%$ Diesel (1.17 €/tonne/kg) and $81 \mathrm{wt} \%$ petrol (unleaded): $1.97 € / \mathrm{kg}$ This ratio is a representative mix of fuel used by cars in Europe [28]

Table 13 Cost estimates of product forming methods

\begin{tabular}{ll}
\hline Production method & Costs $(€ /$ tonne $)$ \\
\hline Film extrusion & 870 \\
Blow molding & 180 \\
Injection molding & 420 \\
\hline
\end{tabular}

necessary for the production, and the limited number of process steps. As a consequence, the polypropylene price was higher in 2005 than in 2000. We assumed the same relationship for the prices of the other petrochemical inputs
(LDPE, styrene, and maleic anhydride). As a result, we defined the price ranges shown in Table 12.

The price range for nanoclay was based on estimates from various sources, while the price range for the PP-glass fiber composite was an estimate from Wageningen University and Research Centre [45].

The costs for the conversion of plastic granules to the final product were estimated on the basis of information from a plastics processor (Landré Werkmetaal b.v., Vianen, The Netherlands) and are given in Table 13. It should be noted that these are very rough estimates. The uncertainty has, nevertheless, been neutralized to a large extent, because a comparative assessment was performed and the
Table 14 Results life cycle costing

\begin{tabular}{lllr}
\hline & $\begin{array}{l}\text { Life cycle costs } \\
\text { conventional product } \\
(€ / \text { /functional unit) }\end{array}$ & $\begin{array}{l}\text { Life cycle costs } \\
\text { nanocomposite product } \\
(€ / \text { /functional unit) }\end{array}$ & Difference (\%) \\
\hline Case 1 & & & \\
Packaging film & 6.44 & 6.39 & -0.8 \\
Agricultural film & 2877 & 1857 & -35.5 \\
Automotive panel & 251 & 237 & -5.4 \\
Case 2 & & & -2.8 \\
Packaging film & 7.92 & 7.70 & -38.9 \\
Agricultural film & 4007 & 2448 & -5.8 \\
Automotive panel & 260 & 245 & +7.9 \\
Case 3 & & & -26.6 \\
Packaging film & 6.44 & 6.95 & -3.2 \\
Agricultural film & 2877 & 2111 & +4.2 \\
Automotive panel & 251 & 242 & -32.6 \\
Case 4 & & & -3.6 \\
Packaging film & 7.92 & 8.26 & \\
Agricultural film & 4007 & 2702 & \\
Automotive panel & 260 & 250 & \\
\hline
\end{tabular}


Table 15 Required nanoclay price reduction to make nanocomposite packaging film competitive

\begin{tabular}{lcc}
\hline & $\begin{array}{l}\text { Nanoclay price } \\
(€ / \text { tonne) }\end{array}$ & $\begin{array}{l}\text { Required reduction } \\
\text { in nanoclay price }(\%)\end{array}$ \\
\hline Case 1 & 4400 & 0 \\
Case 2 & 4400 & 0 \\
Case 3 & 10000 & 50.9 \\
Case 4 & 10000 & 33.6 \\
\hline
\end{tabular}

conventional polymers and the nanocomposites for each product were processed in the same way.

In order to account for the price range given in Table 12, we calculated the production costs for four cases:

1. Low nanoclay price-Low price other material inputs

2. Low nanoclay price-High price other material inputs

3. High nanoclay price-Low price other material inputs

4. High nanoclay price-High price other material inputs

The price ranges of the input data could be accounted for by performing a cost analysis for these four cases.

\section{Interpretation of the Results}

Table 14 shows that, in the cases with high nanoclay costs, the life cycle costs of nanocomposite packaging film are higher than those of conventional packaging film. In contrast, the life cycle costs of the nanocomposite agricultural film and automotive panels are consistently lower than those of the conventional products. The differences are largest between the nanocomposite and the conventional agricultural film. This can be explained by the fact that weight reduction was highest for the nanocomposite agricultural film. Although the weight reduction was only $1.25 \%$ for the automotive panels, the nanocomposites have lower life cycle costs due to the relatively high costs of the $\mathrm{PP}-$ glass fiber composite (=conventional material).

Nanocomposite packaging film has higher life cycle costs in Cases 3 and 4 because its production requires many more production steps and material inputs than the conventional packaging film, which consists only of neat polypropylene. The $9 \%$ weight reduction could not compensate for this. A reduction of the nanoclay cost could, however, make the nanocomposite competitive with conventional packaging film in all cases. Table 15 shows the required nanoclay cost reduction. In the worst-case scenario, the nanoclay price must be lowered by $51 \%$, if the initial price level is $€ 10,000 /$ tonne This means that the nanoclay price can be at most $€ 4,900 /$ tonne. In conclusion, all nanocomposite applications (packaging film, agricultural film, and automotive panels) are economically viable at a maximum nanoclay price of around $€ 5,000 /$ tonne. At this price, the use of nanoclay in agricultural film offers very considerable cost savings.

\section{Conclusions}

The production of nanoclays and their incorporation in nanocomposites have an impact on the environment that may be compensated for if the weight reduction resulting from the use of nanocomposites is large enough. When a polypropylene nanocomposite is used for agricultural film, for example, there are clear environmental benefits due to the high estimated weight reduction. The use of a nanocomposite for packaging film and automotive panels, however, has no obvious environmental benefit.

From an economic point of view, the use of a nanocomposite in packaging film is advantageous if the nanoclay price is not higher than $€ 5,000 /$ tonne Depending on which material and energy prices are assumed, the life cycle costs can be reduced by $26-39 \%$ when a polypropylene nanocomposite is used for agricultural film. We estimated the economic advantage of using nanocomposites in automotive applications to be 3-6\%.

Based on the results of this study, we can conclude that the use of nanocomposite polypropylene can have clear environmental advantages over conventional material in certain circumstances. These advantages are mainly caused by a reduction in the amount of material needed, which depends on material properties like the Young modulus and tensile strength. We found, for example, a high increase in these properties compared to those of LDPE, which explains the large reduction in material. There were only small improvements (12\% improvement in tensile strength) compared to neat polypropylene. Compared to glass fiberreinforced polypropylene, the only improvement was reduced density. The Young modulus was even worse.

The use of polypropylene nanocomposites, therefore, only has advantages when it replaces polymers with less favorable material properties, e.g., LDPE.

It should, however, be stated that there are no disadvantages in using nanocomposites. In general, the nanocomposites do not have a higher environmental impact than conventional products. Moreover, they show some economic benefits when used in agricultural film and automotive panels and definite environmental benefits in the case of agricultural film. One exception to the use of nanocomposites may be the toxic effects of free nanoparticles: more research is required on this topic. Provided the potential release of free nanoparticles from polymer nanocomposites can be excluded as source of concern for human health and the environment, the outcomes of the 
three PP nanocomposite cases clearly support further polymer research and technology development.

Acknowledgements This study has been supported by the EUNetwork of Excellence NANOFUN-POLY "Nanostructured and Functional Polymer-based Materials and Nanocomposites". We thank Dr. Andreas Leuteritz and Dr. Bernd Kretzchmar from the Institute of Polymer Research (Dresden, Germany) for their kind cooperation in generating life cycle inventory data for the production of nanoclay.

\section{References}

1. Hong CH, Lee YB, Jho JY, Nam BU, Hwang TW (2005) Int J Autom Technol 6:665-670

2. Chen L, Wong S-C, Liu T, Lu X, He C (2004) Deformation mechanisms of nanoclay-reinforced maleic anhydride-modified polypropylene. Published online in Wiley InterScience ( http://www.interscience.wiley.com)

3. Leuteritz A, Pospiech D, Kretzschmar B, Willeke M, Jehnichen D, Jentzsch U, Grundke K, Janke A (2003) Adv Eng Mater 5:678-681

4. Sinha Ray S, Okamoto M (2003) Prog Polym Sci 28:1539-1641. Available online at: http://www.elsevier.com/locate/ppolysci

5. Lloyd SM, Lave LB (2003) Environ Sci Technol 37:3458-3466

6. Ashby MF (2005) Materials selection in mechanical design, 3rd ed. Elsevier Butterworth-Heinemann, Burlington

7. Brune DA, Bicerano J (2002) Polymer 43:369-387

8. ISO 14040 (1997) Environmental management - life cycle assessment - principles and framework. International standard organization report. ISO 14040:1997(E)

9. PRé Consultants (2006) SimaPro 7, Multi User 7.0.1

10. Dreyer CM, Niemann AL, Hauschild Z (2003) Int J LCA 8(4):191-200

11. Gothic Arch Greenhouses, Tomato Greenhouse. http://www.gothicarchgreenhouses.com/Tomato_House.htm, accessed 10/03/2006

12. ExxonMobil (2003) ExxonMobil LDPE, LD 166BA Blown Film Resin. http://www.exxonmobilpe.com, accessed 10/03/2006

13. Association of Plastics Manufacturers in Europe (APME), Brussels, Belgium. A material of choice for the automotive industry. http://www.plasticseurope.org/Content/Default.asp?pageid=89, (1999), accessed 07/07/2006

14. Center for the plastics engineering. Nanocomposite materials, http://www.cdcmp.it/englishversion/ricerca_eng.html, accessed 20/12/2005

15. Reichert P, Nitz H, Klinke S, Brandsch R, Thomann R, Mülhaupt R (2000) Macromol Mater Eng 275:8-17

16. Kato M, Matsushita M, Fukumori K (2004) Polym Eng Sci 44:1205-1211

17. Kretzschmar B, Pospiech D, Leuteritz A, Jehnichen D, Janke A, Tändler B (2003) Process design for melt compounding of PP/ clay-nanocomposites. Third world congress nanocomposites 2003, San Francisco 10-12.11.2003

18. Manias E, Touny A, Wu L, Strawhecker K, Lu B, Chung TC (2001) Chem Mater 13:3516-3523

19. Oya A, Kurokawa Y, Yasuda H (2000) J Mater Sci 35:1045-1050

20. Dell'Anno G (2004) Development of a new class of hybrid reinforced thermoplastic composites based on nanoclays and woven glass fibers. Master thesis, University of Pisa, http://etd.adm.unipi.it/theses/available/etd-02052004-113442/, accessed 27/10/2006

21. Hasewaga N, Kawasumi M, Kato M, Usuki A, Okada A (1998) J Appl Sci 67:87-92
22. Svoboda P, Zeng C, Wang H, Lee LJ, Tomasko DL (2001) J Appl Polym Sci 85:1562-1570

23. MatWeb, material property data. Available at http://www.matweb.com, accessed 31/03/2006

24. APME Ecoprofiles (2000) Data collected by Boustead consulting: ecoprofiles of chemicals and polymers. Published by APME Brussels

25. Energy Efficiency Office (1993) Energy consumption guide 31; the moulding of thermo-plastic containers by the extrusion-blow moulding process, $\mathrm{p} 11$

26. Qiu W, Mai K, Zeng H (1998) J Appl Polym Sci 71:1537-1542

27. APME Ecoprofiles (2005) Data collected by Boustead consulting: ecoprofiles of the European plastics industry. http://www.plasticseurope.org/Content/Default.asp, accessed 27/ $10 / 2006$

28. Spielmann M, Kägi T, Stadler P, Tietje O (2004) Life cycle inventories of transport services. Ecoinvent report No 14. Swiss Centre for Life Cycle Inventories, Dübendorf, p 63

29. Phylipsen D, Kerssemeeckers M, Blok K, Patel M, de Beer J (2002) Clean technologies in the materials sector - current and future environmental performance of material technologies. Report Commissioned by European Commission's Institute for Prospective Technological Studies (IPTS), Ecofys, Department of Science, Technology and Society, Utrecht University, Utrecht

30. Doka G (2003) Life cycle inventories of waste treatment services. Ecoinvent report No 13, Swiss Centre for Life Cycle Inventories, Dübendorf, December 2003. Part II - Waste incineration, p 50

31. Kellenberger D, Althaus H-J, Jungbluth N, Künniger T (2003) Life cycle inventories of building products. Final report ecoinvent 2000 No 7. EMPA Dübendorf, Swiss Centre for Life Cycle Inventories, Dübendorf, $\mathrm{CH}$, Online-Version under: http://www.ecoinvent.ch. Part XIX, p 23

32. Althaus H-J, Chudacoff M, Hellweg S, Hischier R, Jungbluth N, Osses M, Primas A (2004) Life cycle inventories of chemicals. Ecoinvent report No 8. Swiss Centre for Life Cycle Inventories, Dübendorf, pp 412-414, 636-640

33. Nemecek T, Heil A, Huguenin O, Meier S, Erzinger S, Blaser S, Dux D, Zimmermann A (2004) Life cycle inventories of agricultural production systems. Final report ecoinvent 2000 No 15. Agroscope FAL Reckenholz and FAT Taenikon, Swiss Centre for Life Cycle Inventories, Dübendorf, $\mathrm{CH}$, retrieved from: http://www.ecoinvent.ch, pp 145-146

34. Jungbluth N (2003) In: Kellenberger D, Althaus H-J, Jungbluth N, Künniger T (eds) Life cycle inventories of building products. Final report ecoinvent 2000 No 7. EMPA Dübendorf, Swiss Centre for Life Cycle Inventories, Dübendorf, $\mathrm{CH}$, Online-Version under: http://www.ecoinvent.ch, pp 16-18

35. Faist Emmenegger M, Heck T, Jungbluth N (2003) In: Dones R et al (eds) Sachbilanzen von Energiesystemen: Grundlagen für den ökologischen Vergleich von Energiesystemen und den Einbezug von Energiesystemen in Ökobilanzen für die Schweiz. Final report ecoinvent 2000 No. 6-V, Paul Scherrer Institut Villigen, Swiss Centre for Life Cycle Inventories, Dübendorf, $\mathrm{CH}$. Online: http://www.ecoinvent.ch, p 116

36. Frischknecht R, Faist Emmenegger M (2003) In: Dones R (ed) Sachbilanzen von Energiesystemen: Grundlagen für den ökologischen Vergleich von Energiesystemen und den Einbezug von Energiesystemen in Ökobilanzen für die Schweiz. Final report ecoinvent 2000 No. 6, Paul Scherrer Institut Villigen, Swiss Centre for Life Cycle Inventories, Duebendorf, CH. OnlineVersion under: http://www.ecoinvent.ch, pp 35, 44, 52, 88, 89

37. Jungbluth N (2004) In: Dones R (ed) Sachbilanzen von Energiesystemen: Grundlagen für den ökologischen Vergleich von Energiesystemen und den Einbezug von Energiesystemen in Ökobilanzen für die Schweiz. Final report ecoinvent 2000 
No. 6-IV, Paul Scherrer Institut Villigen, Swiss Centre for Life Cycle Inventories, Duebendorf, CH, pp 187, 216

38. Guinée JB, Gorrée M, Heijungs R, Huppes G, Kleijn R, de Koning A, van Oers L, Wegener Sleeswijk A, Suh S, Udo de Haes HA, de Bruijn H, van Duin R, Huijbregts MAJ (2001) LCA - an operational guide to the ISO-standards - part 2a. Center of Environmental Science, Leiden, pp 16, 26, 48, 80

39. Pennington DW (2004) Int J LCA OMNIITOX Special Edition 9(5):281-342

40. Pant R, van Hoof G, Schowanek D, Feijtel TCJ, de Koning A, Hauschild M, Pennington DW, Olsen SI, Rosenbaum R (2004) Int J LCA 9(5):295-306

41. US Environmental Protection Agency (2005) Nanotechnology white paper, external review draft. Science Policy Council, US Environmental Protection Agency, Washington, DC 20460, pp $35-38$
42. Lauterwasser C (2005) Opportunities and risks of nanotechnologies. Report in cooperation with the OECD International Futures Programme. Allianz Center for Technology, London/Ismaning, pp 30-32

43. Oberdörster G, Oberdörster E, Oberdörster J (2005) Environ Health Persp 113(7):823-839

44. Rebitzer G, Seuring S (2003) Int J LCA 8(2):110-111

45. Wageningen UR (2004) Patent on natural fiber composites. http://www.agrofibrecomposites.com/patent.htm, accessed 13/04/ 2006

46. Eurostat. Electricity prices industrial users, 1995-2005 average. http://epp.eurostat.ec.europa.eu, accessed 27/10/2006

47. Kosten storten en verbranden van afval, 1985-2005. In: Milieuen Natuurcompendium. MNP, Bilthoven, CBS, Voorburg en de WUR Wageningen, 14 September 2005 